\title{
5. Sung Tales in Héla Húli
}

\author{
Gabe C. J. Lomas
}

\section{Sociocultural context}

The Húli people live in the central mountains of the Papua New Guinea mainland, and number some 250,000 (Haley 2007:155). Across the language community there are minor dialectal variations associated with areas of migration (Lomas 1988:27-30), but these do not significantly affect communication. However, as regards the neighbouring Duna, Dugaba, and Obena peoples, language does affect communication - despite a Húli claim that they share a common ancestor called Héla — since each group speaks a language largely unknown to the others.

In Héla Húli, the tradition of chanting tales around the fire at night is found everywhere and has been a feature of Húli society from time out of mind. These tales, lasting for anything from a few minutes to several hours, ${ }^{1}$ are called bi té, ${ }^{2}$ or 'talk clump/cluster/stand'. ${ }^{3}$ Women chant bì té sitting with groups of women, men with groups of men, and while the primary purpose of these tales is to provide diversions, they treat social relationships and experiential knowledge that reflect many of the sociocultural values of the Húli community. Thus, they also teach ideational and behavioural norms, and, indeed, women have traditionally used bì té as a form of "infotainment" for their daughters and other girls, while boys and young men are always among those who listen to and are influenced by the tales sung by men.

Nowadays, although Húli society is changing, and schools, politics, money, local businesses, and the creeping spread of AIDS are causing ever increasing concerns and taking up more and more community attention, bì té performances continue to be esteemed and respected.

\footnotetext{
1 Pugh-Kitingan (1981:332, and also this volume) says "a few seconds to several minutes or hours." I have not heard any very short bi té, nor any very lengthy ones. The longest I remember lasted about twenty minutes. 2 In this chapter, the usual linguistic conventions are followed as far as possible in transcribing Húli. However, the programs used to produce the present publication in its various e-book forms have trouble in displaying letters with both a tilde $(\sim)$ - indicating nasalization — and an accent. Because of this, it has been decided to represent nasalization with an underlining (_), which then allows the nasalized item to display an accent, too, if necessary. The other diacritics used are: a grave accent (') to indicate words uttered on a falling tone; an acute accent (') to show words with rising tones; and a macron $\left(^{-}\right)$for level tones. Since tone is perturbed in the singing of bì té, Húli transcriptions of bì té texts and any quotations taken from them do not carry diacritics. Note that post-consonantal $w$ signals consonantal labialization, and dots within Húli words indicate morpheme boundaries.

3 The word té occurs in the collocation ìra té 'stand/cluster/clump of trees', where ìra means 'tree(s)'. It is also possible that the té in bì té could be a derivative of téne 'root'.
} 
Bards have a wealth of traditional tales to draw upon, with generally two or more human characters in each tale. Sometimes a tale may carry a romantic interest, and there is nearly always some sort of supernatural element involved, such as a non-human spirit or a paranormal event. Very often, members of the hāroli 'bachelor cult' figure in the tales, although their status as hāroli is usually implied rather than stated. ${ }^{4}$ Frequently, one of the human characters goes off on a journey, often into a high mountainous rain-forest where dāma 'spirits' dwell. These spirits may be ogre-type beings that eat human flesh, cannibals that devour each other, or slippery tricksters likened to the iba tiri 'eels' that inhabit the waterways.

The setting for each tale comprises the general and specific features of the Húli countryside: swamps, rivers, high ominous mountains with their deep forests and dark caves, cultivated garden plots and their produce, coloured clays, and the artefacts and adornments associated with them, along with the flora and fauna of the landscape and traditional Húli rituals. Such are the referents in bi té.

Each story occurs within the constructs of Húli cosmology and is held to embody "truth," although there is a general reluctance for people to claim that the events of any particular bi té actually occurred, and bards may use modulation to distance themselves from asserting the reality or otherwise of the tales they sing. ${ }^{5}$

There is no special term in Húli for 'bard', such a person being called simply a bi té lāga 'story-utterer/teller'. In the same way, people who perform on musical instruments that enable the articulation of words, such the gà wa 'mouth bow' and hiri júle 'jaw's harp', are simply lāgaru 'utterers' - occasionally bāgaru 'strikers/strummers' — of these instruments. Such skills are acquired mainly by watching and imitating others. From childhood onwards, Húli are exposed to $b i$ té, and snatches of the genre sometimes surface in everyday activities. ${ }^{6}$

Bards become proficient ${ }^{7}$ by paying attention to storytellers, remembering their stories and any special language used, imitating and practising chanting techniques, and making the stories their own. An individual bard will usually know a few tales well, although accomplished performers will have larger repertoires.

\footnotetext{
4 There might be a nexus here between bì té and their Duna equivalent, bi gono 'true talk', which are mostly tales woven round the activities of Duna nane 'bachelors' (see Kendoli; Gillespie and San Roque; and Sollis, all this volume.)

5 Modulation is typically expressed in English as "ought," "would," "should," etc. The grammatical form used to express such meanings is a modal suffix (see Lomas 1988:157-63). I am grateful to Lila San Roque, whose questions (pers. comms.) about Húli “evidentials" prompted me to investigate this bì té characteristic.

6 Goldman (1998:111) records a couple of well-known bi té lines being recycled by children at play.

7 It would be a mistake to think of a Húli bard as a Homeric figure, a sort of wandering entertainer. A better comparison is that of the self-taught mouth-organ player in Western society, who acquires the ability to play a variety of tunes by listening to them, observing other players, and then trying things out.
} 
Tales are sung unaccompanied by musical instruments, and each performance is a new creation in that it is tailored by the bard to suit the audience present. Indeed, there is a sense in which bi té are joint constructions, shaped by the interaction of singer and listeners, the latter being expected to signal their involvement by interjecting $\underline{\underline{e}}$ 'yes' periodically throughout the narrative. This participatory feedback also helps to keep the listeners awake, since bards often maintain rhythm by swaying or shifting slightly from side to side as they chant, and listeners tend to sway in unison with them in the smoke and drowsy warmth of the fire. ${ }^{8}$

The sound-wave printout in figure 1 is a fragment from a film soundtrack in which a bi té is performed around a fire at night. ${ }^{9} \underline{\underline{E}}$ 'yes' is interjected initially to encourage the bard when he first pauses for breath and is then repeated intermittently, often triggered by formulaic markers that end in the vocable, $-o$ [o:]. Notice how the audience sometimes intrudes on the bard's performance and can obscure it. The printout also displays the turn-taking conventions of the bi té genre, ${ }^{10}$ illustrated in a transcription of the rest of the opening segment of Húli igiri mbira (text 1): ${ }^{11}$

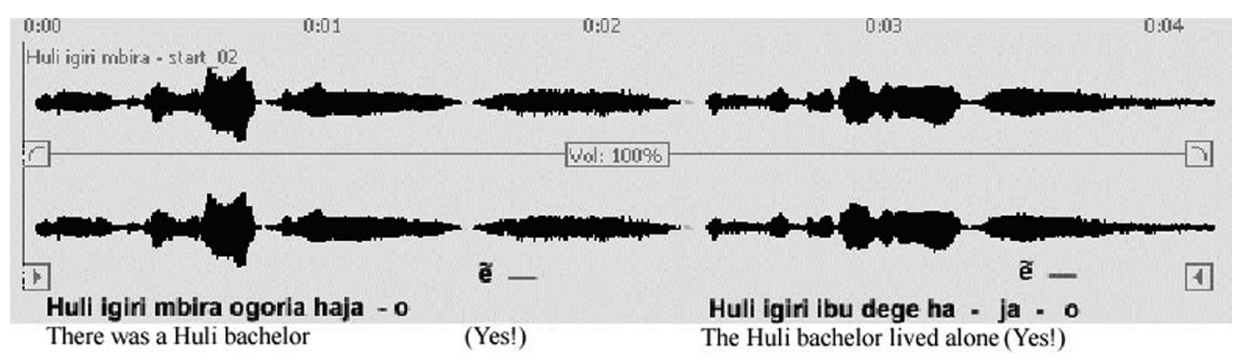

Figure 1. Beginning of Húli ìgiri mbīra.

The sociocultural situations in which bì té are sung are reflected in their storylines and in the characters involved. Bards attempt to convey this through the texture of the language they use, and I propose here to examine that language in an attempt to display the linguistic functions that cause the audience to be moved by and to identify with the characters and events in the tales. But first, it is necessary to say something about the functional model of language that will be used in this discussion and about the Húli language itself, bearing in mind that "the basis of Huli music is language" (Pugh-Kitingan, this volume): a useful insight in regard to the Húli descendants of Héla.

8 Listeners are often warned at the outset to pay attention and to keep saying $\underline{\underline{e}}$ 'yes', lest the bard's mother or their own mothers should die.

9 To be found in Amongst the Huli, an Australian Broadcasting Corporation television film from 1976.

10 Other Húli dialogic genres have their own turn-taking rules—cf. Lomas (1988:347-63).

11 There are more examples of bì té audience participation in Pugh-Kitingan (1981:739-52). The English glosses of bi té transcriptions are arranged to line up with the corresponding Húli as far as possible. This makes them a little uneven at times. 
Text 1. Further transcription of Húli īgiri mbīra (the column between the Húli text and its translation shows the audience response).

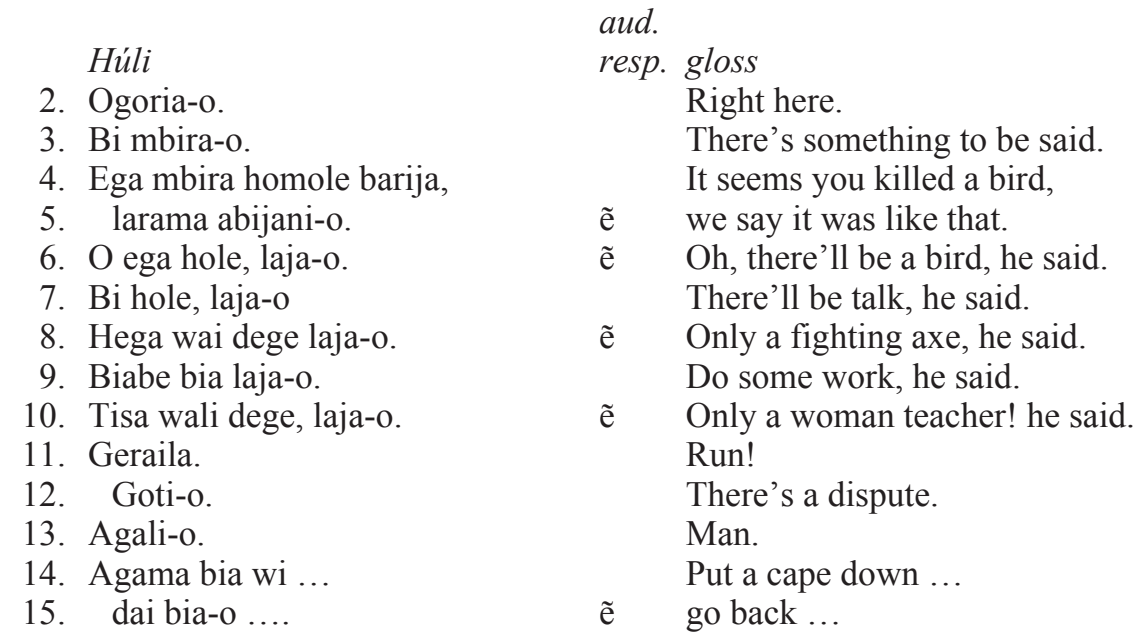

\section{Functional linguistic perspective}

Húli encodes experiential happenings - actions, events, and existential states as semantic configurations called PROCESSES. ${ }^{12}$ Grammatical subjects and objects that figure in these processes are called PARTICIPANTS, either signalled explicitly or implied by devices such as verbal suffixes. Other elements involved are CIRCUMSTANCES, which generally indicate manner and location in time and space. All these items, taken together, comprise semantic categories that explain in a general way how Húli linguistic structures encode the phenomena of the natural world. Typically, processes are realized by verbal groups, ${ }^{13}$ participants by nominal groups, and circumstances by adverbial groups and suffixes.

Underlying all this is a system embedded in the language that covertly classifies the Húli cultural perception of these phenomena, the dual pivots of this system being existential verbs (EV) and adjunct and pro-verb (APV) constructions. ${ }^{14}$ Existential verbs (EVs) categorize the participants to which they refer according to the postures that these referents habitually assume, while adjunct and proverb constructions (APVs) covertly classify different processes, grouping them roughly into the categories AFFECTIVE, EFFECTIVE, ARTIFACTIVE, and LOCATIONAL. This classificatory system plays a role in tracking and predicting the referents in bi té, and the conventions it invokes assist those following the story (figure 2).

12 The labels Process, PARTICIPANT, and CiRCUMSTANCE are taken from Halliday (1994:308-39).

13 The term "group" here refers to grammatical units intermediate between a word and a clause.

14 All abbreviations used are listed in a table at the end of this chapter. 


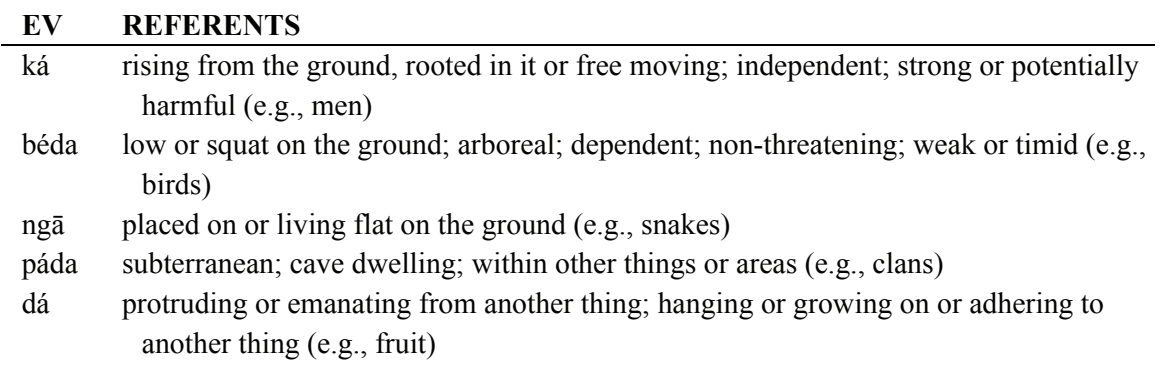

\section{Figure 2. Existential verbs and their referents.}

In figure 2, the existential verbs are shown in their lexicon forms, each having the basic gloss 'is/exists'. These forms are grammatically third-person (3), simple present tense (SmpPres) - that is, $3 \mathrm{SmpPres}$ - although all persons and numbers occur in the SmpPres paradigm of EVs. If the referent's normal posture is altered, the EV can also change-for example, ìra ká 'there's a tree/wood' is used of an upright tree, ìra ngā 'there's a tree/wood' of a tree that has been chopped up; wāli béda 'there's a woman' refers to a woman being present, but wāli ká 'there's a woman' draws attention to her posture or her position.

The 3 SmpPres forms in which the EVs appear do not differentiate for number. Thus, $k a$ is a portmanteau morpheme for all third persons, singular, dual, and plural. As we shall see, when the dāma 'spirit' in the story Àe ndē 'ah yes' goes outside the cave and howls across the hills, the EV $k a$ could refer to a single entity, or to two entities, or to three or more.

126. Ambwa ka ai be, laja,

128. Ne ka ai be, laja,

130. Geloba ka ai be, laja,
"Who's there on Ambwa?" it yelled,

"Who's there on Ne?" it shouted,

"Who's there on Geloba?" it called,

We can predict that $k a$ has as referent(s) an entity or entities that is/are powerful and potentially harmful and, given the setting, that these expected referent(s) is/ are thus probably other dāma. But it is only when the reply comes back, that we can predict that $k a$ in lines 127,129 , and 131 more than likely refers to a single entity on each occasion, and that three other däma have probably now entered the story.

135. O biarume la dai bija.

136. I na hende, i na hende, laja,
Those (spirits) shouted back.

"I saw nothing!" "I saw nothing!" (each) said,

That the referents are indeed dāma becomes apparent as the bì té unfolds.

Another feature of existential verbs is that although they have only SmpPres forms, each EV is semantically linked to a verb that can be affixed for tense and 
aspect, and can thus function as an EV in situations outside the SmpPres. ${ }^{15}$ Thus $k a$ is associated with hé 'be, stand, have'; béda with biru 'sit, squat'; ngā with $w i$ 'place, put, lay'; páda with pálu 'lie down/sleep'; and dá with dé 'extrude, emanate, radiate'. It needs to be noted that the stem-final vowels shown here change according to the suffixes they receive (see Lomas 1988:98-101). An example of this feature of the existential verbs (EV) function is found in the second line of Àe ndē 'ah yes':

2. Agali mbira ogoria ha.ja.

* There was a man living there.

In this example, haja (he.ja) is the third-person simple past (3 SmpPst) of hé 'be/ stand/have' (with the -ja affixed to the Event he-), functioning in this context as the past of $k a$ ' 'is/exists'. Like all third-person affixes, -ja does not discriminate for number, so that in àgali hàlirali 'eight men' (cited later in this chapter) we get:

\section{Agali halirali ogoria ha.ja.}

There were eight men living here.

The second pivotal form of the Húli classificatory system impacting on bi té, and indeed on all Húli utterances, is the adjunct and pro-verb (APV) construction. This consists of an adjunct — a nominal item, such as bi 'talk, speech' — used with a dummy verb, such as $l \bar{e}$ 'utter'. Each dummy verb can be used by itself, but its co-occurrence with an adjunct restricts it to a specific semantic signal, determined by the meaning of the adjunct. Thus, while the nominal bi means 'cry, talk, speech', and the dummy verb $l \bar{e}$ means 'utter', bi lē means 'to talk' or 'to speak'; the nominal manda 'head' in collocation with $b \bar{\imath}$ 'make, do' means 'head do/think'. Similarly, gāmu 'spell, sorcery' in conjunction with $b \bar{l}$ 'make, do' means 'to make sorcery, cast a spell', while ábi 'compensation, wergild' and $b \bar{\imath}$ 'make, do' yield 'pay indemnities'.

In this way, APVs covertly group processes into three classes. Class 1 processes are focussed for the most part on affective, auto-benefactive processes that have their origins with or within the participant that is the grammatical actor; they have dummy verbs that carry the final stem-vowel "e." Class 2 processes have dummy verbs whose final stem vowels are "i," their semantic domain being happenings external to but generated by the main participant. Class 3 processes, ending in stem-final "u," are mainly used of the participant's movements and posture. While these classes are largely ordered by the morphophonemics of the language, they reflect also the boundaries of the semantic domains outlined above, with the overlapping indicated in figure 3. For the (verb) stems in figure 3, $C$ stands for consonant; $X$ is an unspecified number of syllables; $V$ stands for verb; () means "optional"; ${ }^{w}$ indicates labialization; and, $e, i$, and $u$ are the stemfinal vowels.

15 See the discussion of EVs in Lomas (1988:282-85). 


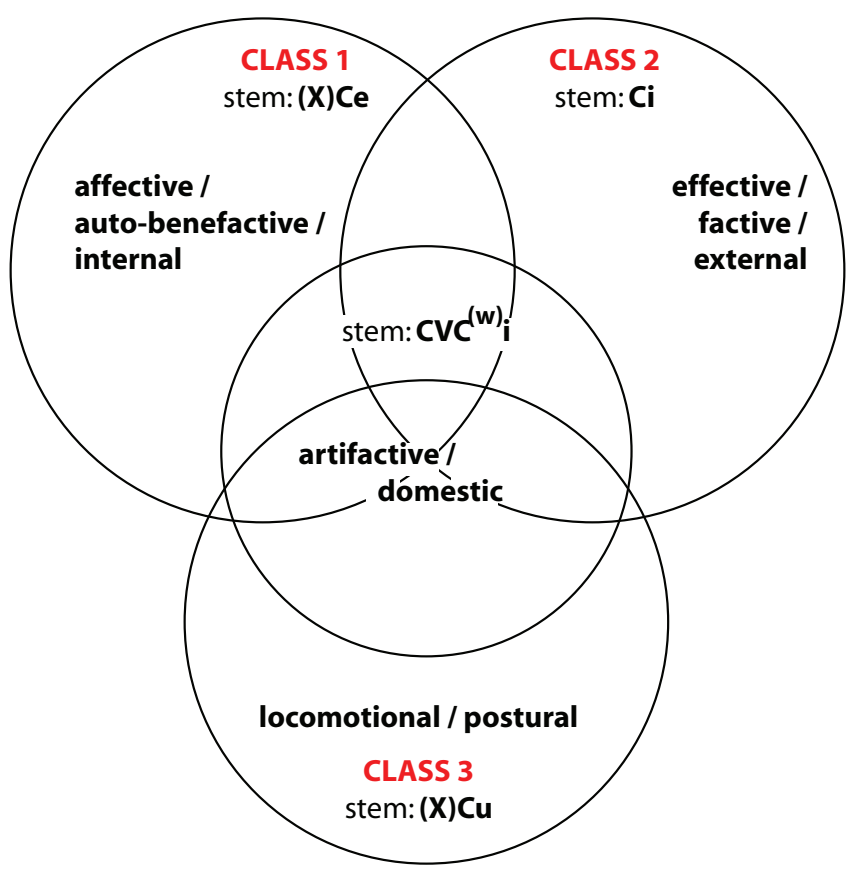

\section{Figure 3. Húli processes.}

The stem of a verb is the core of the process and has the functional label Event (EVN). This core, the Event, can attract suffixes and affixes. The primary affix has the function of relating the process to the location of the speaker in time or in space, and is called the Finite (FIN). Finites can signal time, aspect, modulation, or modality, or they can conflate these operations. ${ }^{16}$ Subsequent affixes function as Auxiliaries (AUX), lending further modality, modulation, or locational specification to the process.

Húli is a verb-final language, and it might be useful to note that the unmarked pattern of grammatical constituents in an utterance or sentence is $(\mathrm{X})(\mathrm{S})(\mathrm{O}) \mathrm{V}$. In this formula, brackets again denote "optional," $X$ is an unspecified number of occurrences of the sequence SOv; $S$ is the grammatical subject, $O$ the grammatical object, $v$ a medial verb (form), and $V$ a non-medial verb (form). In careful (citation) speech aimed at achieving clear communication, a medial verb form always signals that an utterance is incomplete. But bi té is not citation speech, and does not hold consistently to this canonical word order, as we shall see. Nevertheless, the APV system generally confines the bard to the use of certain predictable language functions when describing happenings, and this can help in following bi té storylines - as is illustrated in the use of processes in Àe nde 'ah yes'. ${ }^{17}$

16 My analysis of these points of Húli grammar is considerably influenced by the insights of Foley and Van Valin (1984).

17 See the section "Further Points" at the end of the bi té. 


\section{Textual features of bì té}

The textuality of bi té is made up of structural components and cohesive components. These bind and link the text together to keep it unified and at the same time contribute to its unfolding and development.

Among the structural components is the Topic-Comment (TC) sequence, which operates within clauses but can also be active across clause complexes. The Topic is the participant about which something is being said, while the Comment is what is being said about it. At clause level, the Topic can be indicated by an ergative (ERG) affix or a definitive (DEF) affix, marking the participant to be talked about. Thus, for example, line 24 of $A$ e $n d \bar{e}$ 'ah yes' has the following in which the DEF affix -ni clarifies that it is the bright red pandanus that is being talked about here as being carried in the stringbag.

23. biago.ni hana manda bija-o. he prepared to carry that in his stringbag.

A further structural component creating textuality is information giving, which in many cases shadows the TC pattern by following information that is already known (Given) with fresh (New) data. In sung discourse, the Given-New (GN) structure tends to operate mainly with the internal constituents of a clause, but can also be at work across clause complexes.

Cohesive components that contribute to textuality are reference, ellipsissubstitution, conjunction, and lexical cohesion. ${ }^{18}$ Of these, reference is a relationship between participant or circumstantial elements functioning as a semantic link within or beyond the text. Such relationships are signalled by Deitics (DCs) - linguistic pointing devices, typically pronouns, determiners, and possessives. Examples of referential items are $a$, that, and he in "There was $a$ man living here. Well, one day that man, he ..." (lines 2-4 of Àe ndē 'ah yes' below).

Ellipsis-substitution sets up lexico-grammatical relationships, rather than semantic ones, and can occur in environments such as polar or "yes/no" exchanges, for example,

íbu mīni Maga bè 'is his name Maga?'

ndò 'no' ("his name isn't Maga" is in ellipsis, substituted for Maga, ndò).

Not infrequently, the adjunct of an APV constructions is omitted during exchanges, as in:

íbugwa bi lāja bè 'did he talk-utter' (i.e., 'did he speak')

nāle 'not utter' (nāle substitutes for "he didn't speak," which is in ellipsis).

18 Here the analysis relies on Halliday (1994:308-39), where an explanation of these terms occurs. 
Conjunction typically involves semantic relationships between contiguous elements of the same rank, such as between clauses or between nominal items. One of these relationships is elaboration (shown in analysis by ${ }^{=}$), which is the expansion of one element by another through exposition, exemplification or clarification.

Another relationship is extension (shown by ${ }^{+}$), in which one element attenuates the semantic content of the other by adding to it, or by stating exceptions or alternatives. A third relationship is enhancement $\left(^{\mathrm{x}}\right)$, in which one element qualifies the other as regards location, cause, or manner.

A fourth is locution ("), which is the projection of a process encoding speech, thoughts, or emotions.

Lexical cohesion concerns the relationship between lexical elements, often involving them in two or more cohesive ties. It is typically realized by repetition, the use of semantically linked words such as synonyms and collocations, and by lexical scatter - in particular the scattering throughout a text of key words. The function of this device is to hold the text together as it unfolds, and it does so with cumulative effect.

As we explore bi té texts later in this chapter, instances of some of these types of cohesion will be illustrated.

\section{Bì té and spoken discourse}

While every bi té follows to a large extent a subject-object-verb (SOV) sequence in clauses, medial verb forms sometimes occur in utterance-final position, while in the case of locutions (see Lomas 1988:258-60), the final projecting verb is sometimes deleted. These are characteristics that bi té share with spoken discourse, in which utterances are frequently left unfinished, and new topics are launched whose connection with the one that is being abandoned might only be apparent to those who share the assumptions and expectations of whoever is constructing the text.

Other spoken discourse features in bi té are lexical elisions, irregular grammatical forms, self-correcting tags, and grammatically intricate clause complexes. Nominal groups can involve embedded verbal groups (for details, see Lomas 1988:381 (sect. 12.8.2.7)), which is another indication that bì té are spoken texts being sung. Indeed, although bi té necessarily lack many of the prosodic features of spoken discourse, Pugh-Kitingan (1981:332, 335-36, and also this volume) has shown that the tonal system of spoken Húli impacts on its melodic structure. 
In careful or citation speech, switch-reference-which involves a change in the grammatical subject being referred to-is signalled on verbs in utterancemedial position, but, because bi té are freshly created oral texts-akin to spoken discourse and containing hesitations and re-wordings, and omitting medial verb forms - this referential system does not always work. Thus it is that we can get in bi té such as Àe ndē 'ah yes':

5. Hela Obena pole, lo.wa,

6. manda manda bi.ja-o. having declared, I'll go off to Hela Obena,

(he) got everything ready.

Here, lo.wa 'having said' is a medial verb form and leads to the expectation that the main verb will retain the same grammatical subject - and it does, 3 simple past tense. But further along we find this convention ignored: the affix -alu of the medial verb form anda pi.alu 'going inside' predicts that the same grammatical subject will continue in the next part of the clause - but it does not. At this point, it appears that the referential system has broken down.

\section{0. anda pi.alu, alendo ha.ja,}

(he) going inside, it was afternoon,

This bi té is set within the landscape of the high mountains, and it predictably draws upon appropriate vocabulary. The three registers - or specialized vocabulary sets - that figure most prominently in bì té are kài 'poetry', mána 'lore', and tājanda 'high bush' (Lomas 1988:291-301), all of which include sets of mnemonic, culture-specific, nominal items. ${ }^{19}$ These items sometimes manipulate the vowel harmony system of the language (Lomas 1988:86-97) and, together with other phonological variations introduced by a bard, can give the impression that assonance is a marked feature of bi té performances. However, the incidence of sound correspondence between syllables does not constitute a marked feature of the genre, while, similarly, alliteration - the occurrence of words in close proximity that begin with the same or a similar sound-occurs in many Húli genres and is not an identifying characteristic of bì té. ${ }^{20}$

19 Nominal groups or elements that make them up.

20 It can be seen from a cursory examination of lines 1-11 of $\grave{e} e$ ndē 'ah yes', that sound correspondences occur initially, medially, and finally in words, thus:

\begin{tabular}{|c|c|c|c|c|}
\hline 1 & ae & ae & ...le & la \\
\hline 2 & Aga... & ogo... & ...ria & ...ria \\
\hline $3-6$ & $\begin{array}{l}\text { aga... } \\
\text { manda }\end{array}$ & $\begin{array}{l}\ldots \text {.ago } \ldots \\
\text { manda }\end{array}$ & ...la & ...le \\
\hline $7-11$ & $\begin{array}{l}\text { aga... } \\
\text {...we }\end{array}$ & $\ldots$ le $\quad \ldots$ ago.... & $\begin{array}{l}\text {...wa } \\
\ldots \text {.le }\end{array}$ & $\begin{array}{ll}\ldots \text { we } & \ldots \text { wa } \\
\ldots \text { lo } & \text { lo... }\end{array}$ \\
\hline
\end{tabular}

If we look at a text of té bāme 'desultory speech' that is similar in size, we get similar results. The sound correspondences are shown in bold, thus:

Ani bialu, o ini andaga piru. Ani puwa, o ini hangu andaga biralu, o wali andaga piru. O Paga berearia, o Paga berearia piru. Jawi biabe bule. Jawi magadi pole. E jawi magadi pole bedo.

Both texts show evidence of sounds being echoed across groups two or three times. In the bì té there are at least six groups in which a sound is echoed once and four in which a sound is echoed twice. In the té bāme, the corresponding numbers are something like nine groups with one echo and three groups with two echoes. While not conclusive, this random comparison suggests that assonance is not a marked feature of bi té. 
It must be noted that some bards follow the conventions of phatic discourse genres $^{21}$ (Lomas 1988:334-63) and use simple past (SmpPst) tense affixes, rather than formulaic markers, to elicit the required audience participation, $\underline{e}$ 'yes'. This is one of the consequences of bi té being on a continuum between melodic chanting and recitative declamation.

\section{Àe ndē 'ah yes'}

Each bì té is an episodic speech event, comprised of utterance units that are typically realized as nominal and verbal groups. Bards naturally facilitate the physical delivery of their bi té through pauses for breath, which in turn divide the utterance units into clusters. These clusters may or may not be logically grouped, the function of thus ordering them being performed by formulaic markers that usually append the - $O$ vocable.

The texts presented in this section of the chapter are arranged to display utterance units, usually one per line, and are grouped in logical clusters that I shall call meaning units. This has sometimes meant overriding the groups dictated by the formulaic markers. I shall focus on one tale, Á nde 'ah yes', ${ }^{22}$ in which the marker most frequently used is lārima, ábijani-o 'we said, that's how it was'. However, examples from other tales will also be discussed. ${ }^{23}$

Á $n d \bar{e}$ 'ah yes' uses the traditional theme of a man deciding to go off into the high northwestern mountains and participate in a dàwe ceremony - a dance and pig-kill (often for dead warriors), with the possibility of a courting session at night and the opportunity to acquire another wife. His destination is Héla Óbena, where he will be a stranger to the language and customs of the inhabitants, and where he will have to brave the unknown, relying on the dubious claim of once having shared a common ancestor with them.

The particular version of the tale sung here briefly outlines the man's preparation for the journey, his onerous climb to a place in the high bush where he is accosted by dāma 'malevolent spirit(s)', his dance with and attack on the dāma, and his

21 For example, small talk and other kinds of desultory social exchanges.

22 These tales seldom have names, but I have called this one 'Ae ndē 'ah yes' because the bard frequently uses this phrase as a filler to help him compose his next line. I shall also give names to the other bì té that are cited, such as Húli īgiri mbìra 'a Húli youth', used above.

23 Contamination of data is a constant problem when recording performances of sung tales. The Húli community's $\underline{\underline{e}}$ 'yes' frequently intrudes on the recitation and blots it out - as can be seen from its second occurrence in figure 1-while other background clamour may render segments of a bì té recording unintelligible. There are no audience $\underline{\underline{e}}$ 'yes' responses on the track $\grave{A} e$ ndē 'ah yes'. Situations like this, even when the clear delivery of the text of the bì té is of central importance, contaminate the data. Indeed, any attempt to record a $b i$ té performance, by film, audio-recorder, or simply note-taking, is an intrusion into the authentic situation and introduces variables that the fieldworker has to reckon with. 
return. When the bard got to this last section of the tale, his rate of delivery had slowed a little, and he seemed to cut the narrative short, briefly recapitulating the story and then simply stating that the man went home. ${ }^{24}$

\section{Introductory section: Lines 1-26}

Figure 4 is a sound-wave printout of the first twenty-six lines of $\grave{A} e$ ndē 'ah yes'. The bard received no positive feedback after his first or second breathing pauses. Lack of audience participation might have had an influence on the pattern of subsequent pauses, and was possibly a factor in the precipitous ending he gave to the tale (lines 209-20). That being said, there is still evidence of the bard endeavouring to construe the tale along with the audience by pausing from time to time, often after using the - $O$ vocable that invites hearers to respond.



Figure 4. Sound-wave printout of lines 1 to 26 of $\grave{A} e$ nde.

Figure 4 shows the pace adopted by the bard, and the intervals between pauses. The story is framed between an introductory section (lines 1-26) and a brief summary at the end (lines 211-20). Lines 1-26 tell of the man's decision to travel, his preparation of artefacts and food, and then his departure. This introductory section, displayed in text 2 , does two important things: it sets the scene for the rest of the tale, and it establishes some of the devices that will be used to carry it forward.

\section{Introductory section: Analysis of structural components}

\section{Topic-Comment structure}

The opening clause in line 1 is a formulaic filler that allows the bard to decide how to begin his recitation. The Topic of the next clause, line 2, is the participant agali mbira 'a man'. This Topic is then qualified by the Comment ogoria haja

24 Other variants of this tale omit or telescope some episodes - such as the hero's preparation - but expand other parts of it. Thus, one has the hero roasting a dāma and sprinkling it with salt before going back home. The other dāma slowly return and reveal that they have a cannibal streak when they taste the cooked meat, find it delicious, and set about killing each other to obtain more; see Lomas (1988:380-85). 
'was living here' and becomes marked in line 4 by acquiring the ergative (ERG) affix -me at agali biago.me 'that man'; it is then similarly foregrounded in line 9. In this way, agali mbira 'a man' is set up as the main Topic of the bi té.

Text 2. Introductory section of $\grave{A} e$ ndēe 'ah yes' (* = pause for breath). An audio file of this example can be found in online item 8 .

1. Ae ... ae ale be, laja-o.

2. Agali mbira ogoria haja-o.

3. Mbiru nde,

4. agali biagome, ibu

5. Hela Obena pole, lowa,

6. manda manda bija-o.

7. Ani buwa,

8. ae nde,

9. agali biagome howa,

10. dawe hole pole, lowa

11. - Hela Obena-

12. dawe hagane jaribu manda bija.

13. Hiri lajabi manda bija.

14. Ege nubi manda bija.

15. Ae nde, manda bu

16. Hela Obena pole haja-o.

17. Ae nde,

18. ibugwa alabubabi manda bija.

19. Hiwa degebi manda bija,

20. larima, abijani-o.

21. Goloba angamabi manda bija-o.

22. Ae nde,

23. biagoni hana manda bija-o

24. Ani bijagola howa-o, ae nde,

25. Hela Obena pole, lowa,

26. pija, larima-o.
"Ah, what then?" he said.

* There was a man living here.

Well, one day, that man, he declared, I'll go off to Hela Obena, and got everything ready.

Having done that, ah yes, this man of himself, deciding, "I'll go to a dawe celebration"

* _ - in Hela Obena-

he prepared some dawe accessories.

He got a prize drum ready.

He prepared a stout stringbag.

Ah yes, all equipped,

* he was set to leave for Hela Obena.

Ah yes,

he readied some choice greens.

He prepared a portion of sago, we said, that's how it was.

He got ready some bright red pandanus.

Ah yes,

he prepared to carry this in his stringbag.

* Having done all this, ah yes, he said, "I'm going to Hela Obena," and off he went, we said.

Lines 5-6 are probably best regarded as a single Comment, with Topic-Comment (TC) structures embedded in each of the clauses. Lines 10-12 can be similarly analysed.

Lines 13 and 14 display Topic switches, hiri lajabi 'fine drum' and ege nubi 'stout stringbag' ${ }^{25}$ being the new Topics, each followed by the Comment manda bija 'prepared'. Both clauses are equal, neither dependent on the other, a relationship which is labelled paratactic. They are elaborations of agali biagome ... dawe hagane manda bija 'that man ... prepared some dawe accessories' (lines 9-10),

25 Or: 'a stringbag for ceremonial stones'. However, there is no reference to the use of such stones in this bi té. 
and this elaboration continues through lines 18, 19, and 21. The clauses in these lines display Topic switches and set up manda bija 'prepared' as the Comment in each case.

Line 23 makes a marked return to the main Topic of the bi té, affixing the definitive (DEF) -ni to the determiner (DET) biago 'that (man)', then adding the Comment manda bija 'prepared'. This is a prelude to rounding off the whole of the introduction by foregrounding Hela Obena as the Topic of the medial projecting clause in line 25 (lowa 'he said'), then adding the simple Comment pija 'he went'.

This segment contains an example of "non-canonical" grammar, since careful citation speech would demand that the medial form of -le 'utter' should have the affix - $l u$ 'saying' when the concluding verb is a verb of motion; but here, pija 'he went' follows the medial form, lowa 'having said', which has the affix -wa (see Lomas 1988:126-28).

\section{Given-New structure}

The Given-New (GN) structure of line 2 delivers New information in the collocation agali mbira 'a man' and recycles this as Given in lines 4 and 9 . New information conflates with the Comments ogoria haja 'was living here' (line 2), Hela Obena pole, lowa 'declaring, I'll go to Hela Obena' (line 5) and manda manda bija-o 'got ready' (line 6).

Line 10, dawe hole 'to hold a dawe', can be seen as New, although the semantic link between Hela Obena and dawe could mean that it is socioculturally a Given. Less marginal is dawe hagane jaribu 'dawe accessories', which is a good candidate for being New information. And in this it sets the pattern for the clauses in lines 12,18, 19, and 21, in which New conflates with Topic-each being an exemplification of the New information, dawe hagane jaribu 'dawe accessories' of the clause in line 10 .

The clause in lines 22-23 returns the participant biagoni 'that (man)' as Given and adds hana manda bija-o 'prepared to carry in his stringbag' as New. There is a similar GN:TC conflation in lines 24-26.

\section{Structural components: Summary}

The function of structural components in creating text is to set up elements within clauses and clause chains as items that must be noted and about which things can be said. Known data generally come towards the beginning of a clause, to be followed by data that have not already been presented. This is the anticipated and 
unmarked way in which a text is construed and makes for its communicability. However, occasional departures from these customary patterns can produce a salient texture, the unusualness of which can assist in information-giving.

These introductory lines of Ae nde 'ah yes' indicate how the structural components TC and GN contribute to its textuality. They foreground the main participant, the man, and then hold up for consideration his decision to go on a journey and also the items he prepared for that purpose. Having first the journey, then the artefacts and foodstuffs, construed as Topical and New, foregrounds them and ensures they are communicated as being significant.

\section{Referential cohesion}

Mbira 'one/a' in line 2 is a numeral functioning as a non-specific Deitic, referring to the nominal item that immediately precedes it, agali 'man'. Mbiru 'one day/once/once upon a time' in line 3 is also a numeral functioning as Deitic, its reference being homophoric - that is, pointing inwards to itself, the particular time of the story. In line 4, biagome 'that' refers back to its immediate predecessor, agali 'man', while agali biagome 'that man' is a collocation that refers anaphorically_pointing back - to the collocation agali mbira 'a man' (line 2) and cataphorically - pointing ahead - to its own reoccurrence in line 9. The determiner biagoni 'that one' in line 23 is an anaphoric reference to the other determiners mentioned and possibly reaches back to agali mbira 'a man' in line 2, since the adessive affix - $n i$ adds a greater spatio-temporal reach to the determiner biago 'that'.

Some of the cohesive ties are exophoric, referring to things outside the text of the bi té, such as Hela Obena, line 5, which demands sociocultural knowledge that is not given. Other such exophoric referents are the dawe and the associated artefacts and foodstuff that the man gets ready. This helps to link the tale to the realia of the Húli cosmos.

Thus, these links of semantic cohesion reach forward, beyond this introductory section and into the main body of the bi té itself.

\section{Ellipsis-substitution cohesion}

Line 1 is formulaic (see above), but can also be taken as a direct quotation:

\begin{tabular}{|l|l|l|l|l|}
\hline Ae & $a e$ & ale & be, & laja. \\
\hline Ah & ah & what-like & $?$ & (he) said. \\
\hline
\end{tabular}


The class 1 Affective-internal Process $l \bar{e}$ 'utter/say' with which it ends, follows the projected locution ae ... ae ale be ${ }^{26}$ in which the process is in ellipsis. The omitted process could be reconstructed as one of the existential verbs in figure 2 .

There is a kind of continuous covert elliptical referencing in Húli: the portmanteau morphemes (which simultaneously indicate more than one person or grammatical category) that are the Finites (FIN) and Auxiliaries (AUX) of the affixing system also carry semantic signals for person and number. For example, throughout this bi té, the FIN is frequently -ja, the third-person simple past tense (3 SmpPst) affix that we have met previously and which plays a significant part in tracking the main referents. There are, however, some problems, since -ja and other 3 SmpPst affixes do not discriminate for number and this can cause ambiguities. Some other FINs, such as the purposive (PURP) modal affix -le 'in order to' in lines $5,10,16$, and 25 , go further and signal neither person nor number.

$A n i$ 'thus' in line 7 is a substitution for the adjunct manda manda 'preparation' of the previous line, here in ellipsis. Lexico-grammatical cohesive ties are set up through ellipsis of the reiterative manda from the APV manda manda bija-o 'preparation make/do' ('prepare') in lines 12, 13, 14, 15, 18, 19, 21, and 23. Mànda $b \bar{\imath}$-literally, 'head make/do'-carries the semantic signal 'thought/ knowledge make/do' ('think/know'), so listeners have to ignore this and retrieve the meaning 'prepare' from the APV after line 6.

\section{Conjunctive cohesion: Nominal groups}

The nominal group in line 2 comprises a nominal qualified by a number word that functions as a Deitic, thus:

\begin{tabular}{|l|l|}
\hline Agali & mbira \\
\hline NOM & DC \\
\hline A man \\
\hline
\end{tabular}

Here, the Deitic (DC) elaborates the nominal (NOM) agali 'man' and serves to narrow down its identity. This pattern is repeated in the next nominal group that we meet, which is agali biagome 'that man' in line 4, repeated in line 9.

Hela Obena is a nominal group complex, consisting of two separate nominals in sequence. It is a collocation, which supplies the listener with a familiar and widely understood concept.

Line 12 has the nominal group complex dawe hagane jaribu 'dawe-making artefacts', which can be analysed as two nominals in elaborating - that is, restating or exemplifying - parataxis, the first of which is an embedded nominal group consisting of two further nominals in the same kind of relationship. 


\begin{tabular}{|l|l|l|}
\hline dawe & hagane & jaribu \\
\hline \multicolumn{2}{|c|}{$\mathrm{NOM}^{+2}$} & \\
\hline NOM 1 & \\
\hline \multicolumn{2}{|c|}{ NOM 1 } & $\mathrm{NOM}^{+} 2$ \\
\hline
\end{tabular}

The second of the embedded nominals, hagane 'making', is derived from the customary aspect of the verb ha.ga (see Lomas 1988:123), of the affective autobenefactive process $h \bar{e}$ 'stay/have/be/act' nominalized by the definitive affix -ne, thus:

\begin{tabular}{|l|l|l|}
\hline$h a$ & $-g a$ & $-n e$ \\
\hline STM.stay/have/be/act & CUST & DEF \\
\hline
\end{tabular}

This derived nominal functions in the embedded group as a Classifier (CL), signifying what kind or type of jaribu 'artefacts' are being referred to.

Then, in lines 13 and 14 the content of the concept jaribu is displayed by two non-contiguous nominal groups, each of which contains two items. The first comprises an Epithet (EP) that elaborates on the item that is head of the group, laja.bi 'drum' - which carries the functional label Thing (TH). The second group is made up of two nominals, the first functioning as Classifier of the second. These groups can be shown thus:

\begin{tabular}{|l|l|}
\hline Hiri & laja. bi \\
\hline fine/special & drum. like \\
\hline EP & TH \\
\hline A prize drum \\
\hline
\end{tabular}

\begin{tabular}{|l|l|}
\hline Ege & $n u . \quad b i$ \\
\hline stout/strong & stringbag. like \\
\hline CL & TH \\
\hline A stout stringbag \\
\hline
\end{tabular}

In these groups, it is the strength of the stringbag that is being referred to, likewise the perceived special quality of the drum, both Classifier (CL) and Epithet (EP) embodying the affective attitude of the bard. Similarly, the nominal groups in lines 19 and 21 have EPs that are attitudinal: Hiwa dege 'a (whole) portion of sago' and Goloba angama 'vermillion (not simply red) pandanus'. ${ }^{27}$ The bard wished to tell his listeners what kind of artefacts and (in his opinion) splendid foodstuffs the man prepared.

\section{Conjunctive cohesion: Verbs, verbal groups, and group complexes}

Of the verbs used in lines 1-26, eight are class 1 (affect/auto-beneficial/internal), eleven are class 2 (effective/artifactive/external), and four are class 3 (locomotive/ postural). Not surprisingly, the class 1 verbs chiefly appear when the bard sings of the man deciding to go away; class 2 verbs (in this case, every one is $b \bar{\imath}^{\text {' }}$ make/ do') when he is getting ready; and class 3 verbs (here mostly pù 'go') when his departure is being sung about. 
The initial formulaic clause, line 1, functions to focus the bard's audience on the purpose of the gathering, as well as providing him with a lead-in to his performance.

The clause complex that occurs in lines 4-6 contains a locution, Hela Obena pole (shown by " in the analysis) nested within its projecting clause (CLS), ibu ... lowa, the whole being embedded within a clause that it enhances through a paratactic relationship (indicated by roman numerals in the analysis). This allows the bard to foreground manda manda bija (he can later dispense with one of its adjuncts and still maintain coherence), while continuing the account of the man's decision making.

\begin{tabular}{|c|c|c|c|c|}
\hline agali biagome & $i b u$, & Hela Obena pole & lowa & manda manda bija-o \\
\hline man this & he & Hela Obena in-order-to-go & having said & head head $\mathrm{did} / \mathrm{made}$ \\
\hline & & CLS "3 & & \\
\hline & & CLS ${ }^{x} 2$ & & \\
\hline & & CLS 1 & & \\
\hline
\end{tabular}

Then, lines 7-12 provide us with a complex of six or seven clauses, depending on how they are analysed.

\begin{tabular}{|c|c|c|c|c|c|c|c|c|}
\hline Ani buwa & agali & biagome & howa & dawe & hole & pole & lowa & dawe hagane jaribu \\
\hline thus did & $\operatorname{man}$ & this & being & dawe & to have & to go & said & dawe making artefacts head \\
\hline & \multirow{2}{*}{\multicolumn{3}{|c|}{ CLS $x_{2}$}} & \multirow{2}{*}{\multicolumn{3}{|c|}{ CLS “4 }} & $\operatorname{CLS} \alpha$ & \multirow[b]{2}{*}{ CLS ${ }^{\times} 5$} \\
\hline CLS 1 & & & & & & & $\mathrm{CLS}^{+} 3$ & \\
\hline
\end{tabular}

The relationship between the clauses embedded in the locution is one of hypotaxis, one clause subordinate to the other (indicated here by Greek letters), CLS $\beta$ enhancing CLS $\alpha$ while the relationship between the non-embedded clauses is paratactic, CLS 2 enhancing CLS 1, and CLS 4 being the locution of CLS 3, which extends CLS 2 and is enhanced by CLS 5.

But howa is one of the iba tìri 'slippery eels' of the Húli language (Lomas 1988:170-71) and can often be glossed as 'from', which would conflate clauses (CLS) 2-3 and bring the projecting process lowa into CLS 2. This would produce a complex of just six clauses, with CLS 2 projecting and nesting CLS 3, thus:

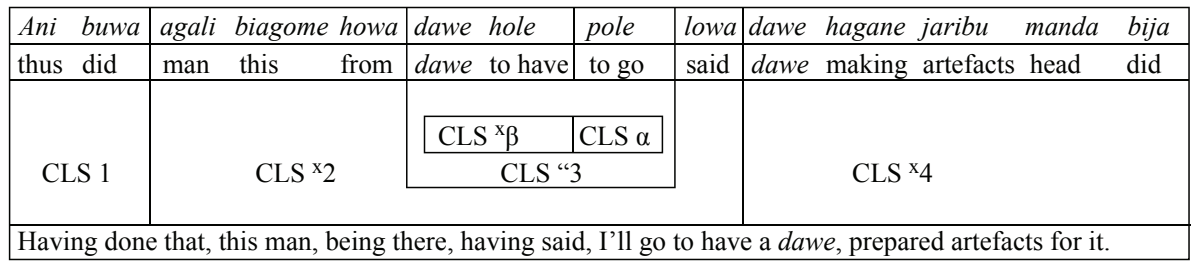


Lines 13 and 14 are both single clauses, but they elaborate on the previous clause in line 15 , exemplifying the jaribu 'artefacts' readied by the man. To do this, they use the repetitive elision manda bija 'readied' and fill the participant slot with a nominal group. This configuration is formulaic, recurring in lines 18,19 , and 21, and being picked up again later in the bì té (lines 154, 156, and 158) to create further cohesive ties.

The clause complex in lines 15 and 16 is unusual, in that $b u$ is the stem form (i.e., Event (EVN)) of $b \bar{\imath}$ 'make/do', and in the form in which it appears here can receive a realis affix (the consecutive aspect -wa (Lomas 1988:142-43)) as its Finite (FIN) or any one of six irrealis affixes. Or it could be the first EVN in a serial two-verb chain, po 'go' with its modal FIN -le 'in order to' being the other. However, the EVN bu 'make/do' does not readily collocate with the EVN po 'go', and the chain would be interrupted by the paired nominal Hela Obena. These factors make serialization an unlikely option.

\begin{tabular}{|ll|ll|l|}
\hline manda & bu & Hela Obena & po. le & ha. ja-o \\
\hline A & PV & & EVN.FIN (mod.) & EVN. FIN (tense) \\
\hline head & done & Hela Obena & in-order-to-go & (he) was/had \\
\hline \multicolumn{4}{|c|}{} \\
\multicolumn{2}{|c|}{ CLS 1 } & \multicolumn{2}{|c|}{$\mathrm{CLS}^{+} 2$} & $\mathrm{CLS}^{+} 3$ \\
\hline \multicolumn{4}{|c|}{ He was ready to go to Hela Obena. } \\
\hline
\end{tabular}

A further clue is the use of $h \bar{e}$ 'is/has' as the non-medial verb in final position, to give the sense of the man being in a state of readiness: recall that $h \bar{e}$ is an associate of the EV - existential verb - ká 'be/exist'. In that case, pole and haja enhance $b u$, and this complex is seen to be three clauses in paratactic enhancement.

However, the clause in line 23 does contain a serial verb string:

\begin{tabular}{|l|l|ll|}
\hline biagoni & hana & manda $\quad$ bi. $\quad$ ja-o \\
\hline NOM & EVN & A & EVN.FIN(tense) \\
\hline this one & carry & head did \\
\hline Participant & \multicolumn{3}{|c|}{ Process } \\
\hline (He) prepared to carry that in his string bag. \\
\hline
\end{tabular}

The bard uses this type of configuration later on in the tale, notably in lines 29-32. Such verbal collocations can become quasi-idiomatic and are apparent in chunks of memorable formulaic text commonly found in bi té.

In the clause complex present in lines 24-26, the projecting clause lowa is an extension of CLS 1, with CLS 4 an extension of CLS 2, of which CLS 3 is a projection. The relationship between each of these clauses is one of parataxis:

\begin{tabular}{|l|l|l|l|}
\hline Ani bijagola howa, & Hela Obena pole & lowa, & pija \\
\hline thus did-when from there & Hela Obena in-order-to-go & (he) having said & (he) went \\
\hline \multicolumn{2}{|c|}{ CLS “3 3} & CLS $^{+} 2$ & CLS $^{+} 4$ \\
\hline Having done that of his own accord, and having decided to go to Hela Obena, he set off. \\
\hline
\end{tabular}


The Mood of the formulaic clause that begins the opening section of $A$ e nde ' ah yes' is interrogative, and is used to focus attention on the audience and its intent. This Mood is then switched to declarative, which is maintained until the end of the section, with some modality used to signal the irrealis of activities not yet completed.

There is a total of twelve clauses in this first section, including four group complexes of three or more. Five of the single clauses are formulaic, elaborating previous clauses by participant substitution and adjunct elision, thus setting up cohesive anaphoric links. The clauses in groups are related mainly in parataxis, the relationships being largely enhancing and extending, with three of the four groups including locutions. These relational ties establish conjunctive cohesion within the verbal groups and verbal group complexes, assisting the logic of the text and thus lending to its coherence.

\section{Conjunctive cohesion: Lexical cohesion}

I shall consider chiefly repetition and lexical scatter, which are in overlap.

Repeated on a fairly regular basis throughout $\grave{A} e$ nde 'ah yes' is the formulaic vocable $-o$ at the end of each meaning unit (recall that a meaning unit is a logical cluster of utterance units). When it occurs, it is appended to the final word in the unit, thus:

$\begin{aligned} \text { 1. laja-o } & \text { said } \\ \text { 2. haja-o } & \text { lived } \\ \text { 6. manda manda bija-o } & \text { prepared } \\ \text { 16. haja-o } & \text { was } \\ \text { 20. larima, abijani-o } & \text { we said, that's how it was } \\ \text { 21. manda bija-o } & \text { readied } \\ \text { 23. hana manda bija-o } & \text { prepared to carry } \\ \text { 26. larima-o } & \text { we said }\end{aligned}$

Of the above, 20 and 26 are formulaic and not part of the narrative. Indeed larima abijani-o quickly becomes the dominant extra-narrative formulaic expression, occurring another forty-two times after this opening section. Variants, such as larima (and even abijani) without the appended -o also occur. Another extranarrative formula, ae nde 'ah yes', occurs nine times, and its variants ae and nde are repeated randomly across the text. Devices such as the repetition and scattering of formulaic lexical items throughout the text function to maintain its cohesion.

Thus, the word agali 'man' occurs in line 2 and is anaphorically referenced in lines 4 and 9, and a further five times later in the tale. Such lexical referencing continues with mbira 'one/a' of line 2 being echoed by mbiru 'one day' in line 3. Then biago(me) 'that' of line 4 is repeated in line 9 and again, as biago(ni) 'that one', in line 23. There are a further nine such anaphoric links to this referent in the rest of the text. 
The key collocation Hela Obena appears in line 5 and then reappears in lines 11,16 , and 25 , forming a cohesive chain that is reactivated again right at the end of the tale in line 214. Its use at line 11 shows the bard consciously breaking the rhythm and sequence of the narration to foreground it as a key lexical item, although it is not clear whether this is done for affective purposes or whether he is using it as a filler to buy himself time.

The item pole 'in order to go' occurs in line 5, and is then repeated in lines 10, 16 , and 25 , and twice more later in the text.

The multiple occurrences of mànda 'head' have been noted. As a lexical item, it first appears in line 6 and is repeated nine times across the introductory twentysix lines, and four more times later in the text. Indeed, the APV (mànda) mànda $b \bar{\imath}$ 'prepare' is akin to a redundant echo utterance that allows the participants in the process to become salient.

Similarly, dawe, introduced in line 10, is repeated in line 12, again near the middle of the tale (lines 162 and 166) and then four lines from the end (line 217).

The items the man prepared for the journey - artefacts in lines 13-14, foodstuffs in lines 18, 19, and 21-are all linked together by the conjunctive morpheme - $b i$ 'and'. This device is repeated later in the text when the man eats (lines 73-77) and prepares to dance (lines 152-59).

\section{Cohesive components: Summary}

Cohesion is aided by anaphoric, cataphoric, and exophoric deixis that link up past and upcoming portions of the text and also tie the text itself into the Húli sociocultural cosmos, and the assumptions and expectations that go with it.

At the same time, conjunctive adjuncts, the omission of adjuncts in APV constructions and the nebulous nature of portmanteau verbal affixes aid cohesion by engaging the listener and forcing her/him to reconstruct the text as it is created by the bard, retrieving meanings from previous portions of it or simply applying acquired inherent knowledge of how the language works.

The bard marshals nominals into groups and group complexes, which adhere through the logical ordering of their linguistic constituents and the semantic ties that are generated. These ties are mostly paratactic, elaborating the qualities of the nominal items with which they are conjoined. Some nominals are derived from verbals and display complex structures, while some nominal groups contain further groups embedded in them. All these various forms are woven together to link up into the texture of the bi té.

Verbs of the three grammatico-semantic classes are used predictably and set up a pattern that discloses their underlying semantic fields. Thus, although class 2 
verbs are well represented in those chunks of text that treat the man's activities prior to leaving, they occur only another fifteen times in the next 196 lines, which are focussed mainly on the affective activities of the bi té characters.

Verbal groups cohere through semantic ties of elaboration, extension, and enhancement, and are mostly in paratactic conjunction. In this way, they hold the tale together and carry its message forward. But these groups require prediction skills on the part of listeners, since the bard sometimes employs elements such as the nebulous howa 'from/having been there' or produces quasi-serial constructions. They assume attentive referential tracking in that they employ a number of portmanteau morphemes that carry no signal for number and sometimes none for person. In later portions of this bi té, there are instances of verbs and verbal groups generating confusion because of lack of concord or because of non-grammatical switching between Topics.

\section{Introductory section: How it works}

This introductory section of $\grave{A} e$ nde shows how the bard uses the language functions at his disposal. There is a cline of consciousness in the choice of these functions, from those over which he has little or no control, to those where control is more conscious and even deliberate. At one end of the cline are functions such as the covert classificatory system that dictates which process types are to be selected and also the portmanteau affixing system that obscures important information about who is involved in the situation or performing the action. ${ }^{28} \mathrm{At}$ the other end of the cline are functions more under the bard's conscious control, such as utterance-initial anaphoric bridges, deitic referencing, self-correcting tags, and the use of the formulaic - $O$ vocable and repetitive echo utterances.

The bard invites his listeners to assent to the message he is delivering and indicates to them when that assent is appropriate. He adds New to previously Given information as he goes along, thus developing the tale as a unit, and chooses when to make Topic changes salient. He configures processes in such a way that they build the story cogently. He imparts his own reactions to the listeners by his choice of wording and through devices such as attitudinal Epithets. He uses a scatter of associated words throughout his text to help its cohesiveness and to maintain its coherence.

There are some functional devices pertaining to the bi té genre that are not displayed in these introductory lines of $\grave{A} e$ ndé, and some that do not occur in the rest of this particular tale, either. The remainder of the story is given as text 3 and is accompanied by brief comments in the following section. In the course of these, I shall deal with bì té characteristics that do not appear in $\grave{A} e n d \bar{e}$. 


\section{Text 3. À ndē 'ah yes', lines 27-220-beginning. An audio file of this example can be found in online item 8 .}

27. Pialu hearia nde,

28. ali gaea mbaria bijagoria-o.

29. O iba na doma,

30. ghangulu iba na doma bija.

31. Iba liba na doma,

32. hundu ale iba na doma bija-o.

33. Diribiwabe godabe,

34. lajani.

35. Golomabu halimbu jajija,

36. larima, abijani-o.

37. Ae nde,

38. ibu pija,

39. larima, abijani-o.

40. Ibu hajagola,

41. lola winiru

42. gili gele henge daja.

43. Ae, lola winiru

44. ndibu ndabu langa daja,

45. larima, abijani-o.

46. Pu gimbu pu gimbu pija,

47. larima, abijani-o.

48. Ibu pialu hearia,

49. anda haubaneni howa;

50. anda pialu, alendo haja,

51. larima, abijani-o.

52. Alendo hajagola, ae nde,

53. anda haubaneni ho bule,

54. palija-o.

55. Ani bijagola howa,

56. anda ho bama leda,

57. larima, abijani-o.

58. Anda anda mbira naibi hearia handaja

59. O biagoria howa

60. aberu leberu

61. mbira baiheru pupu dege wija,

62. handaja-o.

63. O bagoria ubu handaja.

64. Ubu anda handa hearia,

65. (larima, abijane)

66. abe lebe bairu bija-

67. nde, damame uru nalu pijija,

68. laja-o.
Well, while he was travelling,

the weather was very fine there.

Oh, he quaffed and forded water, swallowed and crossed fresh water.

He quaffed and forded deep water,

* swallowed and crossed shallow water.

Pluck some bamboo shoots,

he would have said.

He would have had a staff of strong bamboo, * we said, that's how it was.

Ah yes,

he travelled along,

we said, that's how it was.

While he was going,

strewn across the way

were sparkling leaves, on which he trod.

Yes, there covering the path,

glinting leaves, through which he crunched,

* we said, that's how it was.

He hurried along, on and on,

we said, that's how it was.

As he was travelling, he entered the deep, dark bush; going inside, it was afternoon, we said, that's how it was.

Since it was afternoon, ah yes, he wanted to rest in the deep bush, and he lay down.

After he decided that, going in, he keeps quiet,

* we said, that's how it was.

He saw there wasn't a single house there. There, where he was, someone, yesterday or a couple of days ago left bits of a spirit offering lying around,

* that's what he saw.

He looked around where he was.

While he peered into the bush, (we said, that's how it was) the remains were left one or two days ago"ah, spirits have eaten something and gone," * he said. 
69. Ani pijagola howa,

70. o biagoni na laja dagwa hondowa

71. ira de laja,

72. larima, abijani-o.

73. Ani buwa,

74. alebubabi naja,

75. larima, abijani-o.

76. Hiwa degebi naja,

77. larima, abijani-o.

78. No hajaria howa,

79. ogoria ira de lowa,

80. palija-o.

81. Palearia,

82. mbiraga palene hearia,

83. larima, abijani-o.

84. Dugu dama mbira ela nahe ibuwa

85. andaga bere laja.

86. Gogoraliru au nubi

87. larema abijani-o

88. - emenja-o.

89. Ede beni handade bere laja-o.

90. De lene manda bu hearia,

91. ani bijagola,

92. o biago ibugwa,

93. nde, manda bijagola,

94. o mbira pendole, lowa;

95. agali biago ema nabi palu wija

96. larima, abijani-o.

97. Palearia, o biagome,

98. u pada hajagola howa-

99. ae nde, igiri howa-

100. dehabi handaja,

101. larima, abijani-o.

102. Nguihabi handaja,

103. larima, abijani-o.

104. Halehabi handaja,

105. larima abijani-o.

106. De irihabi ga haja,

107. larima, abijani-o.

108. Ga halu hearia-o,

109. o bagoni mbira ema nabi wija
Since they had departed,

this man, seeing how they had feasted, lit a fire,

* we said, that's how it was.

Having done that,

he ate some choice greens, we said, that's how it was.

He ate the portion of sago, we said, that's how it was.

Having finished eating, and having made a fire here,

* he lay down.

While he was sleeping, darkness fell over his sleeping form,

* we said, that's how it was.

A dreadful, sickening spirit approached, crept inside, and squatted itself down. It's matted hair was like a stringbag, we said, that's how it was

* _ _ it would have been small.

It sat itself down and stared across.

* It readied a lighted brand when there, and when it did that, he himself, well, when it readied it, thought, "I feel there's a presence here"; but this man lay motionless,

* we said, that's how it was.

While he lay there, this spirit, when the man lay asleepah yes, the bachelor lying thereit stared into his eyes, we said, that's how it was.

It scrutinised his nose, we said, that's how it was.

It examined his ears,

* we said, that's how it was.

It sniffed his eyebrows, we said, that's how it was.

While it was sniffing, this man didn't move at all, 
111. Ani bijagola howa,

112. dugu dama biagome nu padaja,

113. -emene biagome.

114. Irani deago dugu mijagola,

115. ge gibanibi hedaja,

116. larima, abijani-o.

117. Agali biagome ema nabi wija,

118. larima, abijani-o.

119. Ge gibanibi hedaja

120. larima, abijani-o.

121. Agali biagome ema nabi wija

122. larima, abijani-o.

123. Ani bijagola howa

124. ibu tagira pijagola

125. (larima, abijani-o)

126. Ambwa ka ai be, laja,

127. larima, abijani-o.

128. Ne ka ai be, laja,

129. larima, abijani-o.

130. Geloba ka ai be, laja,

131. larima, abijani-o.

132. Ogoria mbira wialu pijidago

133. ainaga be, laja,

134. larima, abijani-o.

135. O biarume la dai bija.

136. I na hende, $\underline{\mathrm{i}}$ na hende, laja,

137. larima, abijani-o.

138. Ndo, emene biagome howa,

139. Ibu ngwai handadaba!

140. Ogoria mbira wialu pijidago

141. handamija, laja

142. larima, abijani-o.

143. Ani lajagola howa,

144. o biarume, dama biarume,

145. ngwai haja,

146. larima, abijani-o.

147. Agali biagome berega da hinajagola,

148. (larima, abijani-o)

149. dama biago tagira puwa

150. uju biagoria o lalu hearia tambu

151. larima, abijani-o.
When it had done that,

this dreadful spirit rattled the stringbag,

* - - this little one.

Taking up a firebrand,

it burnt the man's toenails and fingernails, we said, that's how it was.

This man lay motionless, we said, that's how it was.

It scorched his toenails and fingernails,

* we said, that's how it was.

The man lay without moving,

* we said, that's how it was.

After doing this, when it went outside, (we said, that's how it was)

"Who's there on Ambwa?" it yelled,

* we said, that's how it was.

"Who's there on Ne?" it shouted, we said, that's how it was.

"Who's there on Geloba?" it called, we said, that's how it was.

"Someone's gone and left something herewhose is it?" it yelled,

* we said, that's how it was.

These spirits shouted back.

"I saw nothing!" "I saw nothing!" each said,

* we said, that's how it was.

But this little one itself,

"All of you come and look!

Someone's left something here;

let's see what it is," it shouted,

* we said, that's how it was.

After it had said that, these, these spirits, gathered together,

* we said, that's how it was.

The man started up and twisted round, (we said, that's how it was) the spirit, having gone outside, was calling out up there at the same time, * we said, that's how it was. 
152. Ibugwa nde,

153. (larima, abijani-o)

154. ege nubi manda bija,

155. larima, abijani-o.

156. Baru waibi manda bija,

157. larima, abijani-o.

158. Hurwa hulugumabi manda bija,

159. larima, abijani-o.

160. Ani bijagola,

161. (larima, abijani-o)

162. mali dawe uju biagoria

163. tagira pijagola;

164. langulu laja,

165. larima, abijani-o.

166. Mali dawe langulu lajagola,

167. (larima, abijane)

168. dugu dama mo ngwai howa,

169. gi ga, gi ga, laja,

170. larima, abijani.

171. Gi ga, lowa bija handala,

172. mbiru wiaria,

173. (larima, abijane)

174. ira deagome maru laja,

175. larima, abijani.

176. Do kangu lajagola howa.

177. o biagoria imu lu pila haja,

178. larima, abijani-o.

179. Imu lu paji paji bijagola howa,

180. agali biagome howa

181. nama nai tiga wijago

182. ja mijagola howa,

183. (larima, abijani-o)

184. o biago nga, lajagola,

185. dama biago damanego,

186. li ba, nai ba, uju ba,

187. amu ba bija,

188. larima, abijani-o.

189. Baja handala

190. dugu dama emene biarume

191. (larima, abijani-o)

192. dindi hauhabi anda pija.

193. Dandu wiaruhabi anda pija.

194. Ege kaba wiaru anda pija,

195. larima

196. Dindi uli wiaruhabi anda pija,

197. larima abijani-o.
Yes, he himself,

(we said, that's how it was)

prepared a stout stringbag,

we said, that's how it was.

He set up a mirror,

* we said, that's how it was.

He prepared a ceremonial reed skirt, we said, that's how it was.

When he did that,

* (we said, that's how it was)

up towards the dawe dance

he then went outside;

he beat the dawe rhythm,

* we said, that's how it was.

When he beat the dawe dance rhythm, (we said, that's how it was) having gathered the dreadful spirits, he laughed and jeered,

* we said, that's how it was.

As he jeered,

at that time lying there,

(we said, that's how it was)

the wood burnt through at its centre, we said, that's how it was.

* When the fire had died down,

those around it fell into a deep sleep,

* we said, that's how it was.

When they lay around, sound asleep,

* the man himself-

a digging stick was left in the ground there

- he, having grabbed it,

* (we said, that's how it was)

cried out, "Here it is!"

and, this spirit's kin,

he struck out at them left, right and centre,

all over the place,

* we said, that's how it was.

While he was hitting out, those nasty little spirits

(we said, that's how it was)

jumped into piles of loose soil.

They fled into cracks around about.

They rushed into nearby caves, we said.

They slipped into holes in the ground,

* we said, that's how it was. 
198. O biago piai hajagola howa,

199. ega bi laja,

200. larima, abijani-o.

201. Ega bi lajagola

202. agali biagome, hondo habe,

203. lajagola howa-o,

204. ibugwa nu wijaru

205. dugu mu hanajagola;

206. jari wiaru hanajagola;

207. baru wairubi hanajagola howa,

208. pole wijagoria, pija,

209. larima, abijani-o.

210. Ibu pu gimbu pija.

211. Pialu ...

212. anda pialu howa-o;

213. ae, ibu pole wijagoria bamba;

214. Hela Obena pialu howa,

215. anda pialu howa,

216. oba ala halu-

217. mali daweru ngulu lalu;

218. o bagoria halu;

219. ani bialu,

220. nde, dai bini, laja.
* When they had completely scattered, a bird twittered,

* we said, that's how it was.

With the coming of dawn, this man, "Hold on!"

* having said, his stringbag and things lying about, he gathered them up,

put the decorations in his stringbag,

* then, having put in his mirror, he went off, since it was time to leave,

* we said, that's how it was.

Quickly he'd journeyed there and back.

Going along ...

* when he got close to home:

ah, he'd long decided to travel there;

having been to Hela Obena,

and now, close to home,

he laughed aloud-

"A dawe dance and beating the drum; making it there;

and after that,

ah, he'd made it back," he said.

\section{Further points}

The setting for a journey such as this is often a short period of drought (line 28), allowing the bard to use the widely known idiomatic expression found in lines 29-32, the selection of a staff (lines 33-36), jingles associated with crunching through a carpet of dry leaves (lines 40-45), and an idiom for travelling swiftly and tirelessly (line 46). The narrator has tapped into a source of familiar formulaic structures that occur in many bi té.

The covert classificatory system of the language can be seen in that class 3 processes figure largely in sections to do with movement (lines 27-46, 188-96, 209-13) and in sections to do with the deportment of the spirit and the man within the house (lines 84-89, 97-101). Class 1 predominates when the bard is singing of processes that centre on the actor, as in lines $28-36,58-79,98-108$, $141-51,166-87$, and 198-208, while class 2 processes are scarcely represented after line 26 , the focus after that point turning to how the characters are affected, rather what they effect. 
Lines 33-35 show two instances of the bard modifying his claims about the sureness of his text. The AUX -ni affixed to laja 'said' functions as a modal ${ }^{29}$ and modulates the force of the assertion to laja.ni 'would have said'. Similarly, the modal AUX -ja affixed to jaja to produce jaji.ja ' grasped/held/carried' modulates it to 'probably held/carried' or 'would have held/carried'. Besides softening on his own assertions, the bard also uses modulation when describing the man's assessment (line 67) of what had taken place: he affixes the AUX -ja to the verbal pija 'went/left' to come up with nalu pijija 'it seems spirits have eaten here and left'. This attenuates the strength of the man's claim and signals that, based on the external evidence of what had happened, the man conjectures that the spirit must have moved on. Lines 67-68 are analysed thus:

\begin{tabular}{|c|c|c|c|c|c|}
\hline nde & dama.me & uru & na.lu & pi. ji. & la. ja-o \\
\hline conjunction & spirit. ERG & these & eat.SIM1 & go.3 SmpPst.MOD & utter.3 SmpPst \\
\hline
\end{tabular}

The determiner (DET) uru is functioning as an anaphoric Deitic (DC), pointing back to the bits of spirit offering in lines 61 and 66 .

Further modulation is used when recording the dama's cry that someone must have intruded into its domain: wialu pija.da.go 'someone's gone and left something' (lines 132 and 140). In these instances, the modal Auxilliary (AUX) - da (plus the determiner AUX -go 'that one') is affixed to pija 'went/left', indicating that the dama is trying to account for what it currently sees, basing its conjectures on the present evidence before it.

Other bi té also contain examples of bards having recourse to modulation to signal the detachment of themselves or their story characters from the verity of the incidents they relate. Take, for example, these lines from the story Wandari kirali 'two girls' in text $4:^{30}$

\section{Text 4. Extract from Wāndari kìrali 'two girls'.}

5. Nogoru libuni hangu biago.ni.ja balu

6. oali naga.ne.ja, laja-o.
They themselves were alone killing pigs they used to eat here, he said.

The Deitic biago 'that' is suffixed with the definitive AUX - ni to indicate that it refers to the proximate pronoun libuni 'the two themselves', while the modulating AUX -ja signals that there was indirect visible evidence for this at the time referred to. Similarly, the nominalized item naga.ne 'eating' in line 6, which is analysed in the same way as the nominal haga.ne 'having' in line 12 above, carries the same modulating affix, $-j a$.

29 An array of such affixes is available for a bard to modulate from the perspectives of story character and also of performer; see Lomas (1988:124 (sect. 5.2.6), 157, 158-60, 218).

30 This excerpt comes from a recording made in Burani, January 1969. The transcription is by Joseba 
In the course of Àe ndè 'ah yes', the formulaic ábijani-o occurs frequently. This formula comprises the adverbial ábi 'how/like what' with the modal AUX -ja and the definitive AUX $-n e .^{31}$ The final vowel of the definitive AUX assimilates regressively to the [+high] feature of the appended vowel [o:], although in lines 170 and 175 the [o:] was not realized. These affixes together signal that the past indirect visible evidence on which the speaker relies is strong. ${ }^{32}$ Such modulating and distancing of self from claiming actuality for the narrated events occurs in many bi té, and ábijani-o frequently functions to assist this.

The item emenja-o 'little' in line 88 is an instance of a self-correcting tag-as are Hela Obena in line 11 and emene biagome 'that little one' in line $113 .{ }^{33}$ This is a point of affinity between bi té and spoken discourse, both sharing this device.

Lines 90-95 contain a piece of text that illustrates how difficult referential tracking can be. The grammatical actor in lines 90 and 91 is the dāma 'spirit'. Switch-referencing is signalled on the AUX - gola of line 91, and the Deictic biago 'this' refers anaphorically not to the spirit but to the man, elliptically encoded in the portmanteau verbal affixes of lines 80-82. Line 93, with -gola affixed to bija 'made/did', leads to the expectation of a switch back to dāma as actor of lowa 'having said'. But the man is clearly the referent in lines 94-95, which leaves line 93 to be read as a kind of correction or after thought, establishing that the man became aware of the dama as it prepared the lighted brand. Such problems of referent tracking are not uncommon in bi té.

The resolution of another tracking problem, across lines 96-101, is assisted by the exophoric reference igiri 'unmarried man' (line 99) to ibagija 'bachelor initiate', in view of the items he prepared for the dàwe, his rapid and untiring trekking, and his unflinching toughness when tortuously examined-all consistent with the behaviour expected of a member of the häroli 'bachelor cult'. ${ }^{34}$

Lines 126-30 name Ámbwa, Nè, and Géloba, well-known mountains to the north of Tari. This brings into focus a feature of bi té tales: almost every one of them proposes an identifiable landscape in which the tale was enacted. Here it is the high bush up around the Tari Gap, the bard inviting his listeners to enter a region known to be dangerous, with all the fears and tensions that this evokes.

But in other tales, it is lists of known domesticated hāma 'open areas' in the bush or clan grounds that function to establish the landscape. Thus the story Wāndari tèbira 'three girls' ${ }^{35}$ includes a list of places close to the area in which it was performed (text 5):

\footnotetext{
31 See Lomas (1988:158). Another analysis would see ábijani spelt ā bijjani 'how/thus it would have been done'.

32 Compare, e.g., Pugh-Kitingan (1981:740-48 (bì té by Bebalu)).

33 Emenja 'little' is probably an elision of emene 'little' and the modulating affix -ja, to indicate the degree of certainty with which this is stated-i.e., 'it would have been small'.

34 Indeed, David Handabe wanted the text "corrected" to ibagija howa 'the bachelor himself' (Dominic McGuinness, pers. comm.).

35 This excerpt comes from a recording made by Maga Magaja in Burani, January 1969; transcription by Joseba Pungwa, Maga Magaja, and myself, 1969.
} 


\section{Text 5. Extract from Wāndari tèbira 'three girls'.}

Labumabu dagwa pijagola Iba Togo dagwa pijagola Hambuali andaga dagwa pijagola Labumabu andaga dagwa pijagola Ibagija andaga dagwa pijagola
They went to a place like Labumabu They went to a place like Iba Togo They went to a clan-ground like Hambuali They went to a clan-ground like Labumabu They went to a clan-ground like Ibagija

Set formulaic patterns and lists such as this are a feature of bi té, and we have already seen something of them in lines 13-14, 18-21, 152-59, 192-96, and 2047 of À ndè 'ah, yes'. Nominal items can include lists of clan names, coloured clays, bird species, reptiles, types of pig, artefacts, bodily organs, clouds, and so forth. These are part of the affective content of the tale, functioning to evoke emotional states, adding to the tale's effect. More poetically performed parts of a bi té import lists of associated vocabulary from the $k \underline{a ̀ i}$ 'poetry' register to do this, drawing on inventories such as:

\begin{tabular}{lll} 
clouds & bodily organs & clays \\
\hline lúngi & jāma & díndi \\
hálungi & jàmali & dígili \\
jùgai & hígili & ámbwari \\
jàgame & hágai & ámbwago \\
bōgo & lèmbo & méle \\
bógale & lèwale & mèjale
\end{tabular}

These lexical associates are used extensively in other genres that draw on the kài register, notably $\bar{o}$ hé 'keening chant', gà $w \underline{a}$ ' mouth bow', $\underline{\bar{u}}$ 'courting chant', and íba gána 'song' (Lomas 1988:292). The "clouds" listed above function to evoke the notion of wistful beauty; the "bodily organs" to signify affective states and emotions; and "clays" are used to symbolize coloured adornments or significant happenings.

Besides using these linguistic devices to engage the listeners and in a sense to transport them into the realm in which the bi té takes place, there is another device a bard can use. This involves switching from third-person affixes to secondperson affixes, thus seeming to be engaging the story-characters directly as if they were present, ${ }^{36}$ or perhaps addressing the listeners as if they had become part of the saga. Consider the text in text $6:{ }^{37}$

\footnotetext{
36 Cheetham has claimed that third-person singular forms are used for dual and plural, while non-pronominal third-person subjects can attract second-person dual and plural forms in bì té (Cheetham 1978:16-27). PughKitingan (1981:348) called attention to this phenomenon of person-switching in bì té. She considered the possibility that the performer might be talking to the story-characters, but decided that it was "a stylistic device." I thank Laurence Goldman for reminding me of this possible interpretation (pers. comm.).

37 From a recording made by Joseba Pungwa in Burani, January 1969; transcription by Joseba Pungwa, Maga Magaja, and myself, 1969.
} 


\section{Text 6. Extract from Āgali hàlirali 'eight men'.}

1. Agali halirali ogoria haja.

2. Agali halirali ti Nduna jago ogoria haja.

3. Howa, ae

4. hina hiri bo, lowa,

5. irabu timbuni, Ilu li nga ale,

6. ha pirimija-o.

7. Ilu li nga ale puwa,

8. hina hirialu

9. harimija-o.

10. Ae ore, mbiru hai harimi.
There were eight men.

The eight men were from Duna side.

Then, ah,

saying, let's dig up and bake kumara, a big forest, like Ilu up there, into it you all seemingly went.

Having gone up to the place like Ilu, baking kumara, you seemingly remained.

Ah, truly, you stayed a whole day.

The eight men - whose activities quickly reveal them to be häroli 'bachelors'are put in the setting of Mt. Ilu, which is near to where the story was performed. Initially, the text displays grammatical concord, with agreement between the third-person plural subject (the eight men) and the verb form haja 'was', the Finite (FIN) being the portmanteau morpheme $-j a$, the third-person simple past tense ( $3 \mathrm{SmpPst}$ ) affix. But in the next utterance cluster this becomes secondperson plural SmpPst, modulated by the modal AUX -ja (line 7). This signal continues in line 9 , but the modulation is dropped in line 10 . The significant thing has been the switch from third to second person. This means that the bard could have been addressing the eight men as if they were there, or he could have been addressing the listeners themselves.

Similar Person-switching occurs in Wāndari kìrali 'two girls' (text 7):

\section{Text 7. Extract from Wändari kìrali 'two girls'.}

1. Wandari kirali ogoria howi haja-o.

2. Wandari kirali biago libu ogoria howa

3. ae libu hangu biragonijago,

4. biru ore ogoria biru wiribi.
There were once two girls

These two girls, from here, well, the two living all by themselves, you two did well, here together.

At this point it appears that the bard switches to talking to the two girls directly, moving from third-person simple past tense in line 2, to second-person dual SmpPst in line 4, as shown in the analysis:

\begin{tabular}{|l|c|}
\hline wi. & ribi \\
\hline STM. & 2 Dl SmpPst \\
\hline \multicolumn{2}{|l|}{ you two placed/stayed } \\
\hline
\end{tabular}


The two girls go off on a journey and split up, and the narrator immediately returns to using 3 singular $(\mathrm{Sg})$ verb forms. ${ }^{38}$ However, one of the girls meets a young man (häroli) in the bush, and the bard says:

This is the first occurrence of the $2 \mathrm{Pl}$ (plural) form, and the bard now seems to be addressing his listeners, perhaps inviting them to identify with the characters in the tale.

An explanation of some instances of third- to second-person switching might be that the second person could have a generic function in Húli-much as it has in modern English..$^{39}$ Number, no longer signalled grammatically in most varieties of English, is formally realized in Húli by the pronominal and suffixing systems. This would account for third-person dual becoming second-person dual, and third-person plural becoming second-person plural.

However, person-switching does not occur in every bì té, and it is just one of the devices available to bards for use in constructing linguistic texture. Other devices include the choice of appropriate processes and nominal items, the interrelating of groups and group complexes through a variety of semantic and structural ties, the maintenance of cohesive links throughout the narrative by intricate (and generally successful) referential systems, and exophoric links to the shared sociocultural cosmos to provide a setting for the tale. Other linguistic features have been noted in this chapter, but our knowledge will doubtless be further enhanced when trained Húli linguists begin to turn their attention to $b i$ té. Hopefully, they will shed further light on how the Húli language functions to create such highly esteemed tales, and how it coaxes audiences into identifying with the human characters in them.

\section{Acknowledgements}

I wish to record my debt of gratitude to those who have worked with me on the text of $\grave{A} e n d \bar{e}$ 'ah yes', and who have facilitated the production of this chapter: Edward Ekari; Magdalene Kibili; Dominic McGuinness, OFMCap; David Handabe; Samuel Driscoll, OFMCap; Isaiah Dimba, OFMCap; and especially Howard Halu, whose expertise and insights have been invaluable.

\footnotetext{
38 Sydney Gould, who worked among the Húli for twenty years or more, and Laurence Goldman reckon that in spoken discourse people use second-person dual / second-person plural also as third-person dual / thirdperson plural to indicate "continuity" of action - that there is more information to come. If the action is final, then people would use a third-person form (Goldman, pers. comm.).

39 As in the song title, "You've Got to Have Heart!" A more extensive example is: "The three men travelled from Sydney to Alice Springs overland. They carried their camping equipment with them in a four-wheel drive vehicle. You've got to have a sturdy truck for a journey like that. And you can't afford to forget anything essential. Yet, incredibly, they ran short of fuel on the second day."
} 


\section{Abbreviations used}

\section{function} symbol

$=$

$+$

6

3

A

APV

AUX

C

CL

CLS

CUST

DC

DEF

DET

D1

EP

ERG

EV

EVN

FIN

GN

MOD

NOM

$\mathrm{O}$

$\mathrm{Pl}$

PURP

PV

$\mathrm{Sg}$

$\mathrm{S}$

SIM1

SmpPres

SmpPst

STM

TC

$\mathrm{TH}$

V

V

$\mathrm{X}$ meaning

Elaboration

Enhancement

Extension

Projection

2nd Person

3rd Person

Adjunct

Adjunct+Pro-Verb

Auxiliary

Consonant

Classifier

Clause

Customary

Deitic

Definitive

Determiner

Dual

Epithet

\section{Ergative}

\section{Existential Verb}

Event

Finite

Given-New

\section{Modal}

Nominal

Object

Plural

Purposive

$$
\text { Pro-Verb }
$$

Singular

Subject

1st Simultaneous

Simple Present

Simple Past

Stem

Topic-Comment

Thing

Verb / Final Verb

Medial Verb

Unspecified number constituents (of sentence/verb stem)

explanation in more detail by the other

further the value of the other scope of the other

is spoken

pronoun or verbal affix

pronoun or verbal affix

nominal item

nominal item + dummy verb form

affix of verb affixing system

grammatical item

nominal: type indicator

process

verbal aspect; habitual behaviour

indicator; "pointing" word

nominal item or affix

nominal affix

nominal item

nominal affix

denotes simple existence

core of a verb

a verbal affix

a cohesive textual system

verbal aspect/affix

usually realised by nouns/adjectives

grammatical item

three or more

modal verbal affix

verbal item

one; single person

grammatical item

verbal aspect

verbal tense

verbal tense

unaffixed/undeclined item

a cohesive textual system

functional head of nominal group

complete forms in an utterance

incomplete forms in an utterance a relationship between two elements in which one is explained

a relationship between two elements whereby one displays

a relationship between two elements in which one indicates the

a relationship between two clauses, one indicating that the other

pronoun/verb signifying number two 


\section{References}

Australian Broadcasting Corporation. 1976. Amongst the Huli. Television documentary.

Cheetham, Brian. 1978. "Counting and Number in Huli." In "The Indigenous Mathematics Project," edited by David F. Lancy, special issue, Papua New Guinea Journal of Education 14: 18-30.

Foley, William A., and Robert D. Van Valin, Jr. 1984. Functional Syntax and Universal Grammar. Cambridge: Cambridge University Press.

Goldman, Laurence R. 1998. Child's Play: Myth Mimesis and Make-Believe. Oxford: Berg.

Haley, Nicole, ed. 2007. Conflict and Resource Development in the Southern Highlands of Papua New Guinea. Canberra: Australian National University.

Halliday, M. A. K. 1994. An Introduction to Functional Grammar. London: Edward Arnold.

Lomas, Gabe C. J. 1988. "The Huli Language of Papua New Guinea.” PhD dissertation, Macquarie University. http://hdl.handle.net/1959.14/22313. (additional ethnographic section, plus illustrations, at The Huli People of Papua New Guinea: A Study in Sociolinguistic Change, 1998. http://www. GabeLomas.org.)

Pugh-Kitingan, Jacqueline. 1981. "An Ethnomusicological Study of the Huli of the Southern Highlands, Papua New Guinea." PhD dissertation, University of Queensland. 